\author{
Бойко Ольга Степанівна \\ кандидат мистецтвознавства, \\ Київький національний університет \\ культури і мистецтвв, \\ Київ, Украӥна \\ boykoolgast@ukr.net
}

\title{
ТЕЛЕВІЗІЙНІ ТАНЦЮВАЛЬНІ ШОУ В УКРАЇНІ: ІСТОРІЯ І СУЧАСНІСТЬ
}

Мета роботи - дослідити проблемні аспекти та перспективи танцювальних шоу-програм в Україні як однієї з оригінальних форм хореографічного мистецтва в культурному житті нашої країни. Методологія дослідження полягає в застосуванні компаративного й логічного методів, що дає змогу проаналізувати певні аспекти розвитку сфери танцювальних шоу-програм в Україні з метою пошуку динамічного погляду на їх майбутне, нові виміри самореалізації сучасних вітчизняних хореографів, а також в історичному методі, що дає змогу простежити основні етапи становлення та розвитку танцювальних шоу. Наукова новизна. У розвідці вперше проаналізовано телевізійні танцювальні шоу в Україні, розкрито проблеми та перспективи танцювальних шоу-програм. Висновки. Проаналізовано культурну проблематику розвитку вітчизняних танцювальних шоу, що є новим дослідницьким питанням для вітчизняної мистецтвознавчої науки. Осмислення проблем і перспектив танцювальних шоупрограм в Україні дає підгрунття для розвитку вітчизняного хореографічного мистецтва, зокрема створення власних танцювальних шкіл, використовуючи досвід кращих зарубіжного представників.

Ключові слова: шоу, танцювальне шоу, шоуізація, телевізійний проект, мистецтво.

Бойко Ольга Степановна кандидат искусствоведения, Киевский начиональный университет культуры и искусств, Киев, Украина

Телевизионные танцевальное шоу в Украине: история и современность

Цель работы - исследовать проблемные аспекты и перспективы танцевальных шоу-программ в Украине как одной из оригинальных форм хореографического искусства в культурной жизни нашей страны. Методология исследования заключается в применении сравнительного и логического методов, позволяет проанализировать некоторые аспекты развития сферы 
танцевальных шоу-программ в Украине с целью поиска динамического взгляда на их будущее, новые измерения самореализации современных отечественных хореографов, а также в историческом методе, что позволяет проследить основные этапы становления и развития танцевальных шоу. Научная новизна. В научном исследовании впервые проанализированы телевизионные танцевальные шоу в Украине, раскрыты проблемы и перспективы танцевальных шоупрограмм. Выводы. Проанализировано культурную проблематику развития отечественных танцевальных шоу, что является новым исследовательским вопросом для отечественной искусствоведческой науки. Осмысление проблем и перспектив танцевальных шоу-программ в Украине дает почву для развития отечественного хореографического искусства, в частности создание собственных танцевальных школ, используя опыт лучших зарубежных представителей.

Ключевые слова: шоу, танцевальное шоу, шоуизация, телевизионный проэкт, искусство.

Boiko Olha PhD of Arts Study, Kyiv National University of Culture and Arts, Kyiv, Ukraine

\section{Dance television shows in Ukraine: history and modernity}

The purpose of the article is to study the problem aspects and prospects of dance show programs in Ukraine as one of the original forms of choreographic art in the cultural life of our country. The research methodology consisted in the application of the comparative and logical methods, which provided for the analysis of certain aspects of the development of the sphere of dance show programs in Ukraine, in order to find a dynamic view upon their future, and new dimensions of self-realization of modern domestic choreographers, as well as the historical method, which allowed for tracing the main stages of the formation and development of dance shows. The scientific novelty of the work lies in the first of its kind analysis of television dance shows in Ukraine, revealing the problems and prospects of dance show programs. Conclusions. The cultural problematics of the development of domestic dance shows was analyzed, which is the new research question for the national art critical science. Understanding the problems and prospects of dance show programs in Ukraine gives grounds for the development of domestic choreographic art, in particular the creation of private dance schools, using the experience of the best foreign representatives.

Key words: show, dance show, showization, television project, art.

Вступ. У період кін. XX - початку XXI ст. відбуваються кардинальні зміни в історії естрадного мистецтва, з'являються нові жанри, форми. Зважаючи на найбільш динамічний характер серед інших видів мистецтва, естрада про- 
довжує швидко реагувати на потреби часу, запити публіки, посідати одне 3 провідних місць у рейтингу глядацьких переваг. Видовищність хореографічних творів починає превалювати над змістовністю, з'являється низка танцювальних шоу, що зазнають всесвітньої слави. Попри невіддаленість у часі, ці процеси потребують аналізу, зважаючи на їхню масштабність. Останнім часом науковці все частіше піддають аналізу танцювальні шоу-програми в контексті різноаспектних розробок В. Голубенкова [2], С. Дункевича [5], М. Татаренка [13] та ін., однак дослідження, спеціально присвяченого танцювальним шоу не було.

Поняття «шоу» в останні роки активно використовується в мистецькому просторі України. «Шоу» (Show - демонстрація; видовище) - одна з популярних сучасних форм організації дозвілля, особлива форма масового видовища, вистави, характерною особливістю якої є використання елементів театралізації, сучасних технічних та комп'ютерних засобів. О. Медведь 3 філологічних позицій аналізує неологізм «шоу»: «У межах загальновживаного словникового фонду виділяємо запозичення, які за останній час на грунті української мови перетворилися на слова-вершини потужних словотвірних гнізд, що свідчить про їхню високу словотвірну активність i продуктивність уже в межах українського словотворення. Зокрема було виявлено неологізми 3 першими частинами бізнес-, інтернет-, медіа-, онлайн-, піар-, рейтинг-, фітнес-, фолк-, шоу-» [8, с. 80]. Слово «шоу» має в українській мові значення «велика розважальна вистава, видовище розважального жанру» [12, с. 270 ] і є першою частиною похідних номінацій: шоу-балет, шоу-бізнес.

Відповідно до значення поняття «шоу» (видовище), його сутність як специфічного жанру в просторі хореографічного мистецтва доцільно розкривати на семантику «видовища». Згідно В. М. Литвинського, феноменом видовища $\epsilon$ універсальною константою людського існування, що має кросскультурний характер. «Священний ритуал, хід, карнавал, публічна страта, спортивне змагання, театральна вистава утворюють складне явище культури зі своєю структурою та динамікою. Глибокому розумінню цього явища перешкоджають звичні розумові стереотипи, що збереглися від попередньої епохи класичного раціоналізму» [7, с. 54].

Витоки жанру танцювального шоу, на думку В. Голубенкова потрібно шукати в середньовічних карнавалах. Автор вважає, що саме брак видовищності, святковості, карнавальності в мистецтві XX ст. визначив твердження жанру шоу в сценічній хореографії [2, с. 56-61].

Поняття «танцювальне шоу»є багатоаспектним і неусталеним. Діапазон феноменів, що можуть бути означені як танцювальні шоу досить великий: від концертних програм видовищного характеру до драматургічно струнких театралізованих видовищ 3 високотехнологічними спецефектами. Серед атри- 
бутивних рис шоу С. Дункевич називає видовищність, інтерактивність, презентаційність, маніпулятивність і маркетингова прагматичність, карнавальність, гедоністичність (орієнтація на отримання задоволення), «зірковість» (не лише участь «зірки», а й культивування поклоніння публіки перед володарем цього звання) [5 с. 69-74]. Біологічні передумови шоу, на думку В. Стаметова, зводяться до «соціального імпринтингу»- вродженої схильності до копіювання поведінки, яку транслює лідер. Дослідники обирають різні критерії для визначення поняття «шоу»: характерні ознаки для будь-якого видовища взагалі, постмодерністську специфіку, комунікативну складову, соціокультурну специфіку, онтологічні виміри. Така розмаїтість підходів свідчить не лише про масштабність та багатофункціональність означеного феномена, а й про його глибоке проникнення в усі сфери життя суспільства. Це явище вчені називають «шоутизацією». Так, Н. Дубовик приходить до висновку, що шоу виходить за межі телебачення та індустрії розваг, стаючи сучасною карнавалізованою формою культури, що дозволяє автору говорити про явище «шоутизації» [4, с. 224].

Власне тлумачення терміна «шоуізація» подає Ю. Романенко у «Проективному філософському словнику», дослівно перекладаючи це слово як «показуха» [9]. На думку автора, шоуізація - це настанова для сучасної цивілізації, обумовлена тотальним розповсюдженням засобів масової інформації і комунікації, яка має вираження в маніпуляції зором натовпу, в постійному прагненні подати будь-які факти і явища на розсуд для широкого загалу, задовольнити гіпертрофовані психологічні потреби у видовищах. Шоуізація полягає в експансії візуальної культури, яка повинна вплинути на уяву звичайного телеглядача шляхом безперервного відстеження і демонстрації в режимі non-stop екстраординарних подій, використовуючи дві основні форми шоуізаційної подачі матеріалу - сенсацію та ексклюзив. Гасло шоуізації - шоу повинно тривати за будь-яких обставин [9, с. 89-96].

У процесі вивчення телешоу не можна оминути загальні дослідження шоу як феномена культури (І. Коротаєва), шоу-технологій та загальної шоуізації суспільства (К. Акопян, Н. Дубовик, А. О. Скрипка).

Вітчизняне телебачення орієнтується на виробництво розважальних шоу, формат яких вже апробований у США та Європі. Одним 3 найяскравіших таких зразків є танцювальні шоу, що поєднують у собі хореографічну майстерність та змагання учасників-конкурсантів, які демонструють свої здібності й уміння. Наявність таких шоу на екрані, прискіплива увага до таких шоу журналістів, дані соціологічних опитувань про високий рейтинг подібних передач обумовлюють актуальність дослідження цього питання. 
Виклад основного матеріалу. У сучасному світі танець для кожного може бути як засобом самовираження, так і комерційним медіапродуктом. Сьогодні, без сумніву, телевізійні танцювальні шоу є одним із основних складових сучасного мистецтва нашої країни, які розраховані на потреби пересічного телеглядача. Сучасні телевізійні танцювальні шоу характеризуються масштабністю події, масовістю, видовищністю, а глядач не лише переглядає шоу, а де-факто стає його співучасником.

В Україні досить розгалужена індустрія танцювальних шоу-програм, підтвердженням цього $\epsilon$ телевізійний проект світового рівня «Танцюють усі!» Це формат шоу «So You Think You Can Dance?» («Думаєш, ти вмієш танцювати?») британської компанії RDF. Уперше проект «Танцюють усі!» стартував в Україні навесні 2008 р. Він став українською адаптацією британського шоу «So You Think You Can Dance?». Проект проходив у 4 етапи. Спочатку на пошуки талантів відправлялися продюсери, які переглядали учасників в обласних центрах України. Згодом відбувався телевізійний кастинг у чотирьох містах України, де танцюристів оцінювало професійне журі. На третьому етапі учасників очікував тиждень у Ялті (100 кращих), де 3 ними працювали професійні хореографии, тоді там визначилася двадцятка кращих танцюристів країни (10 хлопчиків і 10 дівчаток). Потім був фінал у прямому ефірі, за правилами якого щотижня два учасники (хлопчик і дівчинка), за оцінками журі, вибували із конкурсу, а остаточне рішення ухвалювали телеглядачі.

Телепроект «Танці з зірками» (Strictly Come Dancing) за форматом BBC стартував в Україні наприкінці 2006 р. на каналі 1+1. Прикметно, що шоу «Танці з зірками» вважають піонером цього жанру в телепросторі України у найбільш класичному світовому ракурсі, хоча ще раніше глядачам пропонувалися телеканалом Інтер такі шоу-проекти, як «Шанс» та «Караоке на майдані».

У вересні 2008 р. на телеканалі «1+1» стартувало танцювальне шоу «Танцюю для тебе» за форматом «Dance for a dream» мексиканської компанії Televisa. Репетиції проекту проходили у залах на кіностудії ім. О. Довженка. В ньому взяло участь вісім пар, у кожній з яких - «зірка» та «мрійник», який танцює заради здійснення мрії талановитої дитини. Серед зірок, які були залучені до програми, спортсмени Яна Клочкова та Олег Лісогор, співак Джанго, актор «Comedy Club Ukraine» Дядя Жора, співачка Альона Вінницька, актриса Катерина Кузнєцова та актор Дмитро Лаленков. У парі 3 ними виступили відомі в Україні хореографи - Олена Шоптенко, Дмитро Дікусар, Ксенія Горб та ін. Вели програму Юрій Горбунов та Інна Цимбалюк.

Шоу витримало декілька сезонів, дещо змінюючи склад учасників та принципи їх відбору. Так, особливістю третього сезону стало те, що партнерів «зірок» відбирали на відкритому кастингу. Олена Шоптенко, Сергій 
Костецький і Дмитро Дікусар стали наставниками-хореографами трьох пар. Такий формат шоу, коли хореографи посередництвом успіхів свої підопічних змагаються між собою, отримав назву «Битва хореографів». Переможцями третього сезону стали А. Безсонова та О. Лещенко, які танцювали заради мрії юного талановитого акробата з Києва Давида Антоняна. Значення і особливість шоу найкраще прокоментував генеральний директор групи компаній «1+1» О. Ткаченко: Третій сезон «Танцюю для тебе» продемонстрував, що телебачення здатне виконувати соціальну функцію - вперше головними героями проекту стали не зірки, не гості, не танцюристи, а талановиті діти, заради їхніх мрій і танцювали учасники. А кількість меценатів, які долучилися і взяли участь у долі дітей, тільки підтверджує цю тезу. Крім того, цей сезон, на наш погляд, був найбільш технологічним - рівень танцювальної майстерності, який продемонстрували пари, гідний професійного визнання. Таким проектом можна пишатися». Окрім того, третій сезон запам'ятався глядачам сценою, яка світилася, і оригінальними дизайнерськими конструкціями.

На жаль, 4 сезону проекту не відбулося, незважаючи на його соціальну спрямованість. Все ж таки танцювати заради реалізації мрії талановитої дитини це була справжня революційна і благородна ідея, яка, утім, чомусь не прижилася в українському телепросторі. У цій ситуації дуже доречні слова Є. Гуцала: «Будь-який телевізійний продукт, що створюється сьогодні, передусім виходить 3 комерційних цілей, 3 цілей бізнесу, що, без сумніву, приводить до оперування трьома категоріями: «товар - культура - мораль», що, звісно, відбивається на кінцевому підсумку програм такого роду» [3, с. 183].

Сьогодні один 3 найвідоміших каналів «Україна» не пропонує своїм глядачам жодного танцювального шоу, однак на початку 2014 р. він випустив для перегляду шоу «Пристрасті на паркеті». Це українська адаптація британського формату «Stepping out», в якому брали участь 9 пар, до складу кожної з яких входила одна українська знаменитість та ії друга половинка. До складу зіркового журі увійшли Лайма Вайкуле, Свген Папунаішвілі і Олена Коляденко (постановник шоу). Назва шоу відповідає назві проекту «пристрасті», оскільки за задумом авторів глядачам, крім танцювальних номерів, пропонувавлася інформація про підготовку до виступів, спілкування, сварки і навіть скандали.

У 2013 р. на каналі «Інтер» глядачам було до вподоби шоу, в якому брали участь повні люди, які мріють схуднути - «Великі танці». У проекті учасниками були 5 жінок і 5 чоловіків. Чотири місяці учасники жили в заміському будинку, найбільше часу вони проводили в танцзалі, а також працювали 3 психологами, дієтологами, танцюристами i головними хореографами проекту Оленою Шоптенко та Дмитром Дікусаром. 3 кожною парою займався професіонал, 
наприкінці тижня 5 пар продемонстрували в ефірі те, чого вони досягли, як в танцях, так і в боротьбі з зайвою вагою. Їх виступи оцінює професійне журі, і до суми балів суддів додається коефіцієнт схуднення учасника. Долю двох пар, які набрали найменшу кількість балів, вирішує глядач за допомогою інтерак-тивного голосування.

У 2011 р. канал «Інтер» репрезентував унікальний проект, на думку його авторів, виробництва Friends Production «Шоу №1», особливістю якого стало поєднання вокальних і хореографічних талантів учасників.

Головне гасло ведучих Філіпа Кіркорова та Ані Лорак: «Ми зробимо 3 тебе зірку!». Кастинги на участь у вокально-танцювальному проекті пройшли в 27 містах країни. Було відібрано талановитих учасників для формування 10 команд по 10-12 осіб у кожній.

Кожна програма «Шоу № 1»- це справжня вистава, феєричний концерт за форматом Freemantle. Кожна команда готувала власну постановку. Групиучасниці різного віку демонстрували різноманіття музичних жанрів: від попмузики до року, джазу і а-капельного співу. Переможцем стала не одна людина, а вся команда, що принципово відрізняє це шоу від інших подібних.

Навесні 2011 р. наймасовішим танцювальним телевізійним проектом в Україні було шоу «Майдан’s», яке організував телеканал «Інтер» і Київська міська державна адміністрація, а виробником стали студія «Квартал-95» і компанія «Star Media». Після вдалого старту першого сезону (у перших п’яти випусках шоу частка аудиторії в середньому становила 14,2 \% (вік 18+, міста 50+ тис.) за невпинного зростання цього показника) у вересні вийшов у ефір другий сезон. Третій сезон стартував 18 серпня 2012 р.

У шоу брали участь команди з найбільших міст України, в кожній з яких були сотні людей. Під керівництвом відомих хореографів учасники команди готували танцювальні постановки, які щосуботи представляли 2 міста на Майдані Незалежності в боротьбі за звання Танцювальної Столиці України.

Під час змагання працював телеміст 3 центральною площею кожного з міст-учасників, а сам виступ проходив у три етапи: карнавальна хода кожної команди на Хрещатику, індивідуальний танець кожної з команд та спільний танець двох команд (дві команди виступають одночасно під одну музичну композицію).

Телевізійні танцювальні шоу України можна систематизувати за колективним та індивідуальним спрямування у визначенні переможців. Так, колективна змагальність характерна для таких шоу, як «Майдан’s» та «Шоу № 1». Загалом для танцювального формату більш характерною є індивідуальна форма визначення переможців. Загалом ми нарахували вісім таких проектів. Об'єднуючою їх характеристикою є підпорядкування одній тематиці, змагання, тобто визначе- 
ння переможців, телевізійний формат. Відмінність між проектами - це віднесення перших до категорії шоу талантів (від англ. malent show), в якому може взяти участь будь-яка людина, щоб продемонструвати свої унікальні здібності. Натомість друга категорія танцювальних проектів спрямована на залучення до участі в них вже відомих учасників, що й визначило, наприклад, назву «Танці з зірками». Так, у новому сезоні телепрограми у прямому ефірі глядачі мають змогу спостерігати за змаганнями на паркеті українських зірок, серед яких Влад Яма, Надя Дорофєєва, Дантес, Володимир Зеленський та ін. При цьому формат шоу і першої, і другої групи - це справжній музично-танцювальний концерт з яскравими режисерськими вирішеннями, постановкою танцювальних номерів та захоплюючою атмосферою, що панує не лише на майданчику, а й за кулісами під час підготовки учасників до виступів.

Висновки. Отже, дослідивши проблематику даного наукового дослідження, можемо зробити такі висновків, що: танцювальні шоу-програми є одним із видів хореографічного мистецтва, які дуже динамічно розвиваються на теренах Україні. Телевізійні танцювальні шоу України можна систематизувати за колективним та індивідуальним спрямування у визначенні переможців. Загалом для танцювального формату більш характерною є індивідуальна форма визначення переможців. Маємо вісім таких проектів. Об'єднуючою їх характеристикою $\epsilon$ підпорядкування одній тематиці, змагання, тобто визначення переможців, телевізійний формат. Вони є одним із видів культурно-дозвіллєвої сфери, і мають характерні театральних риси: сценарій розвитку шоу, розважальний характер, світло, музика, костюми тощо. Хочемо зазначити, що в постановці українських танцювальних шоу використовуються не лише національні елементи танцю, а й за основу беруться кращі європейські танцювальні зразки; переважна більшість танцювальних телевізійних шоу-проектів в Україні пов'язана комерційною складовою.

\section{Список використаних джерел}

1. Акопян К. 3. Шлягеризация, шоуизация, эксгибиционизация в современной культуре / К. 3. Акопян // Горизонты культуры: от массовой до элитарной : Материалы IX ежегодной междунар. конф. 16-17 нояб. 2007 г. Санкт-Петербург : Санкт-Петербург. филос. общество, 2008 - С. 20-21.

2. Голубенков А. Г. Танцевальное шоу в системе жанров сценической хореографии /А. Г. Голубенков // Вісн. Міжнар. Слов'ян. ун-ту. Серія «Мистецтвознавство». - 2008. - № 1. - С. 56-61.

3. Гуцал Е. А. Реалити-шоу: некоторые аспекты типологии / Е. А. Гуцал // Известия Уральского федерального университета. Серия 1: Проблемы образования, науки и культуры. - 2009. - Т. 62. - № 1/2. - С. 179-184. 
4. Дубовик Н. Шоутизация современной культуры / Н. Дубовик // МІСТ: Мистецтво, історія, сучасність, теорія : зб. наук. пр. - 2010. - № 7. - С. 224-233.

5. Дункевич С. Г. Танцевальное телевизионное шоу как элемент визуальной культуры (на примере проекта «Танцы со звездами») / С. Дункевич // Ученые записки Таврического нац. ун-та имени В. И. Вернадского. Серия «Философия. Культурология. Политология. Социология». - 2014. - Т. 27(66). № 1. - C. 69-74.

6. Коротаева И. В. Шоу-программы как феномен массовой культуры / И. В. Коротаева // Вестн. Казан. гос. ун-та культуры и искусств. - 2008. - № 1. C. 29-31.

7. Литвинский В. М. Ускользающая красота зрелища / В. М. Литвинский // Научные исследования и разработки в спорте. Вестн. Санкт-Петербург. гос. акад. физической культуры им. П. Ф. Лесгафа. - Санкт-Петербург, 1999. C. $45-54$.

8. Медведь О. В. Юкстапозиція як актуальний спосіб інноваційного творення загальновживаних слів і термінів (нормативний аспект) / О. В. Медведь // Гуманітарний часопис. - 2014. - № 4. - С. 79-83.

9. Проективный философский словарь : новые термины и понятия / под ред. Г. Л. Тульчинского, М. Н. Эпштейна. - Санкт-Петербург : Алетейя, 2003. $512 \mathrm{c}$.

10. Скрипка А. О. Шоу-технології як форма соціальної комунікації : автореф. дис... на здобуття наук. ступеня канд. соціол. наук : спец. 22.00.04 «Спеціальні та галузеві соціології» / А. О. Скрипка ; Харк. нац. ун-т ім. В. Н. Каразіна. - Харків, 2010. - 19 с.

11. Станіславська К. Феномен талант-шоу на сучасному телебаченні / К. І. Станіславська // Культура і сучасність. - 2013. - № 2. - С. 89-96.

12. Словник іншомовних слів [Електронний ресурс] / за ред. O. С. Мельничука. - Режим доступу : http://www.rozum.org.ua/index.php?a=term $\& \mathrm{~d}=18 \& \mathrm{t}=37074 .-$ Назва $з$ екрану.

13. Татаренко М. Г. Діяльність хореографа-постановника в масових видовищних заходах / М. Г. Татаренко // Актуальні проблеми історії, теорії та практики художньої культури : зб. наук. пр. - Київ, 2014. - Вип. 33. - С. 299304.

\section{References}

1. Akopyan, K. (2008). Schlagerization, showization, exhibitionization in modern culture. Horizons of culture: from mass to elitist: Materials of the IX annual international conference. Saint-Petersburg, The Republic of Russia, 16-17 November, 2008. Saint-Petersburg: Sankt-Peterburgskoe filosofskoe obshchestvo. 
2. Golubenkov, A. (2008). Dance show in the system of genres of stage choreography. Visnyk Mizhnarodnoho Slovianskoho universytetu. Seriia «Mystetstvoznavstvo» [Bulletin of the International Slavic University. Series «Art Criticism»].

3. Gutsal, E. (2009). Reality show: some aspects of typology. Izvestiya Ural'skogo federal'nogo universiteta. Seriya 1: Problemy obrazovaniya, nauki $i$ kul'tury [Izvestiya of Ural Federal University. Series 1: Problems of Education, Science and Culture], vol. 62, no/1/2, pp. 179-184.

4. Dubovik. N. (2010). Showization of modern culture. Mystetstvo, istoriia, suchasnist, teoriia [Art, history, modernity, theory], no. 7, pp. 224-233.

5. Dunkevich, S. (2010). Dance television show as an element of visual culture (through the example of the project «Dancing with Stars»). Uchenye zapiski Tavricheskogo natsional'nogo universiteta imeni V. I. Vernadskogo. Seriya «Filosofiya. Kul'turologiya. Politologiya. Sotsiologiya» [Scientific notes of Taurida National Vernadsky University. Series "Philosophy. Culturology. Political science. Sociology»], vol. 27(66), no. 1, pp. 69-74.

6. Korotaeva, I. (2008). Show programs as a phenomenon of mass culture. Vestnik Kazanskogo gosudarstvennogo universiteta kul'tury i iskusstv [Bulletin of Kazan State University of Culture and Arts], no. 1, pp. 29-31.

7. Litvinsky, V. (1999). The escaping beauty of the spectacle. Scientific research and development in sports. Bulletin of the St. Petersburg State Academy of Physical Culture named after PF Lesgaf [Nauchnye issledovaniya i razrabotki $v$ sporte. Vestnik Sankt-Peterburgskoi gosudarstvennoi akademii fizicheskoi kul'tury imeni P. F. Lesgafa], pp. 45-54.

8. Melnychuk, O. Eds. (1974). Dictionary of foreign words. Available at: $\langle$ http://www.rozum.org.ua/index.php?a=term\&d=18\&t=37074> [Accessed 10 December].

9. Medved, O. (2014). Juxtaposition as an actual way of innovative creation of commonly used words and terms (normative aspect). Humanitarnyi chasopys [Humanitarian magazine], no. 4, pp. 79-83.

10. Skrypka, A. (2010). Show technology as a form of social communication. D. Ed. Kharkiv National University named after V. N. Karazin.

11. Stanislavska, K. (2013). The phenomenon of talent show on modern television. Kultura i suchasnist [Culture and modernity], no. 2, pp. 89-96. 
12. Tatarenko, M. (2014). Activity of the choreographer-director in mass entertainment events. Aktualni problemy istorii, teorii ta praktyky khudozhnioi kultury [Actual problems of history, theory and practice of artistic culture], issue 33, pp. 299-304.

13. Tul'chinskii, G., and Epshtein, M. Eds. (2003). Projective philosophical dictionary: new terms and concepts. Sankt-Peterburg: Aleteiya.

(C) Бойко О. С., 2017 